\title{
A STABILITY INDICATING RP-HPLC METODS FOR SIMULTANEOUS ESTIMATION OF THE ABACAVIR, LAMIVUDINE AND DOLUTEGRAVIR IN BULK AND PHARMACEUTICAL DOSAGE FORM
}

\author{
Srinivas Lella*, P. Venkateswararao and N. Srinivasrao \\ Department of Pharmaceutical Analysis and Quality Assurance, \\ Vikas College of Pharmacy, Vissannapeta-521 215, Nuzvid, \\ Tirvur, Andhra Pradesh, India.
}

\begin{abstract}
A simple, accurate, precise method was developed for the simultaneous estimation of the Abacavir, Lamivudine and Dolutegravir in solid dosage form. Chromatogram was run through Discovery C18 $150 \times 4.6 \mathrm{~mm}, 5 \mu$. Mobile phase containing Buffer and Acetonitrie in the ratio of $65: 35 \mathrm{v} / \mathrm{v}$ was pumped through column at a flow rate of $0.8 \mathrm{ml} / \mathrm{min}$. Buffer used in this method was $0.01 \mathrm{~N} \mathrm{KH} 2 \mathrm{PO} 4$ buffer at $\mathrm{pH} 4.5$. Temperature was maintained at $30^{\circ} \mathrm{C}$ Optimized wavelength for Abacavir. Lamivudine and Dolutegravir was $225.0 \mathrm{~nm}$. Retention time of Abacavir, Lamivudine and Dolutegravir were found to be $2.338 \mathrm{~min}$, $3.275 \mathrm{~min}$ and $3.870 \mathrm{~min} \% \mathrm{RSD}$ of system precision for Abacavir, Lamivudine and Dolutegravir. were and found to be 0.4, 0.4and 0.4 respectively.\% RSD of method precision for Abacavir, Lamivudine and Dolutegravir.
\end{abstract}

Keywords: Abacavir. Lamivudine, Dolutegravir and RP-HPLC.

\section{INTRODUCTION}

Abacavir

Abacavir $(A B C)$ is a powerful nucleoside analog reverse transcriptase inhibitor (NRTI) used to treat HIV and AIDS. Chemically, it is a synthetic carbocyclic nucleoside and is the enantiomer with $1 \mathrm{~S}, 4 \mathrm{R}$ absolute configuration on the cyclopentene ring. In vivo, Abacavir sulphate dissociates to its free base. IUPAC Name $^{1,2,3 .}:[(1 \mathrm{~S}, 4 \mathrm{R})-4-[2-a m i n o-6-$

(cyclopropylamino)-9H-purin-9-yl]cyclopent-2en-1-yl]methanol,(figure1).

\section{Lamivudine}

A reverse transcriptase inhibitor and zalcitabine analog in which a sulphur atom replaces the 3 ' carbon of the pentose ring. It is used to treat Human Immunodeficiency Virus Type 1 (HIV-1) and hepatitis B (HBV). Chemical name ${ }^{1,2,3}$ : 4-amino-1-[(2R,5S)-2(hydroxymethyl)-1,3-oxathiolan-5-yl]-1,2dihydropyrimidin-2-one.(figure 2).

\section{Dolutegravir}

Dolutegravir is indicated for HIV-1 infection for adults and children and adolescents $\geq 12$ years of age and weighing $\geq 40 \mathrm{~kg}$. It is marketed as Tivicay as Dolutegravir sodium. $52.6 \mathrm{mg}$ of Dolutegravir sodium is equivalent to $50 \mathrm{mg}$ Dolutegravir free acid. FDA approved on August 12, 2013. Chemical name ${ }^{1,2,3}:(3 S, 7 R)-$ $\mathrm{N}$-[(2,4-difluorophenyl)methyl]-11-hydroxy-7methyl-9,12-dioxo-4-oxa-1,8diazatricyclo [8.4.0.0] tetradeca-10,13-diene-13carboxamide,(figure 3).

Analytical methods play a vital role in new drug development, preformulation and formulation studies, stability studies, quality control testing and quality assurance programmes. So analysts are always in search of developing rapid and accurate new methods of analysis that are able to exist in routine analytical work. The review of literature reveals that only few chromatographic methods have been reported for the estimation of Abacavir Lamivudine and Dolutegravir like LCMS, LCNMR MS, HPLC ${ }^{4-6}$. 
There is a need for developing newer methods in HPLC for developing a simple and economic method and so we proceeded with HPLC and validated as per the $\mathrm{ICH}$ guidelines. The present analytical work comprises of simple, precise, rapid, sensitive and accurate methods for the estimation of Abacavir Lamivudine and Dolutegravir bulk and dosage form.

\section{EXPERIMENTAL}

Instrumental specification Waters HPLC 2695 series with quaternary pumps, Photo Diode array detector and auto sampler integrated with empower software column used was C18 $150 \times 4.6 \mathrm{~mm}$

\section{MATERIALS AND METHODS}

Abacavir Lamivudine and Dolutegravir working Standard was obtained from Spectrum pharma research solutions pvt. Ltd, Hyderabad and commercial dosage forms containing the studied drug were obtained from local market. All the reagents used were analytical reagents, solvents were of HPLC grade

\section{Buffer Preparation \\ 0.1\%OPA Buffer}

$1 \mathrm{ml}$ of ortho phosphoric acid was diluted to $1000 \mathrm{ml}$ with HPLC grade water.

\section{$0.01 \mathrm{~N} \mathrm{KH}_{2} \mathrm{PO}_{4}$ Buffer}

Accurately weighed $1.36 \mathrm{gm}$ of Potassium dihyrogen Ortho phosphate in a $1000 \mathrm{ml}$ of Volumetric flask add about $900 \mathrm{ml}$ of milli-Q water added and degas to sonicate and finally make up the volume with water then $\mathrm{PH}$ adjusted to 4.5 with dil. Orthophosphoric acid solution

\section{Mobile Phase}

Buffer and Acetonitirile were mixed in the ratio of $65: 35 \mathrm{~V} / \mathrm{V}$ and sonicated to degas.

Preparation of Standard stock solutions: Accurately weighed $75 \mathrm{mg}$ of Abacavir, 37.5 $\mathrm{mg}$ of Lamivudine and $6.25 \mathrm{mg}$ of Dolutegravir and transferred to three $25 \mathrm{ml}$ volumetric flasks separately. $10 \mathrm{ml}$ of Diluent was added to flasks and sonicated for 20mins. Flasks were made up with water and methanol (50:50) and labeled as Standard stock solution 1, 2 and 3.

Preparation of Standard working solutions (100\% solution): $1 \mathrm{ml}$ from each stock solution was pipette out and taken into a $10 \mathrm{ml}$ volumetric flask and made up with Water methanol.

Preparation of Sample stock solutions: 5 tablets were weighed and calculate the average weight of each tablet then the weight equivalent to 1 tablet was transferred into a $100 \mathrm{~mL}$ volumetric flask, $25 \mathrm{~mL}$ of diluent added and sonicated for $50 \mathrm{~min}$, further the volume made up with diluent and filtered.

\section{Preparation of Sample working solutions ( $100 \%$ solution)}

From the filtered solution $0.5 \mathrm{ml}$ was pipette out into a $10 \mathrm{ml}$ volumetric flask and made up to $10 \mathrm{ml}$ with diluents. (300ppm, 150ppm \& 25ppm).

\section{RESULTS}

\section{METHOD VALIDATION}

The described method has been validated for the assay of Abacavir Lamivudine and dolutegravir using following parameter ${ }^{7-10}$.

\section{System suitability}

The system suitability parameters were determined by preparing standard solutions of Abacavir, Lamivudine and Dolutegravir and the solutions were injected six times and the parameters like peak tailing, resolution and USP plate count were determined. The \% RSD for the area of six standard injections results should not be more than $2 \%$. The results were tabulated in Table 1.

\section{Linearity}

The linearity of an analytical method is to elite test results that are directly, of by well-defined mathematical transformation, proportional to the concentration of analyse in sample within a given working range. The results were tabulated in Table 2.

\section{System Precision}

Prepared and analyzed six replicate sample preparations as per method. And calculate the $\%$ RSD of area of response. The results were tabulated in Table 3.

\section{Repeatability}

Multiple sampling from a sample stock solution was done and six working sample solutions of same concentrations were prepared, each injection from each working sample solution was given and obtained areas were mentioned in the table 4.

\section{Inter day precision}

Prepared and analyzed three replicate for day1 and day-2 sample preparations as per method. And calculate the \%RSD of assay level. The results were tabulated in Table 5.

\section{Accuracy (Recovery)}

Demonstrated the accuracy of the test method by preparing recovery samples (i. e. spiking formulation with known quantities of API.) at 
the level of $50 \%, 100 \%$, and $150 \%$ of target concentration. Prepare the recovery sample in triplicate in each level. The sample was prepared as like assay method. The results were tabulated in Table 6,7,8.

\section{Limit of detection and quantification (LOD and LOQ)}

From the linearity data calculate the limit of detection and quantitation, using the following formula. The results were tabulated in Table 9.

\section{$L O D=3.3 \sigma$$$
\mathbf{S}
$$

$\sigma=$ standard deviation of the response

$S=$ slope of the calibration curve of the analyse

$$
L O Q=\frac{10 \sigma}{S}
$$

$\sigma=$ standard deviation of the response

$S=$ slope of the calibration curve of the analyse

\section{Robustness}

The robustness of an analytical method was determined by analysis of aliquots from homogenous lots by differing physical parameters that may differ but were still within the specified parameters of the assay by changing physical parameters like flow rate mobile phase and $\mathrm{pH}$. HPLC system was set with small but deliberate change in method as mentioned below and their effect on system suitability test and the values were given in Table 10

\section{Assay}

Triumeq $(600+300+50)$ from Vie Healthcare, baring the label claim Lamivudine $600 \mathrm{mg}$ Abacavir $300 \mathrm{mg}$ Dolutegravir $50 \mathrm{mg}$ per unit formulation Assay was performed with the above formulation. The results were tabulated in Table 11, 12, 13.

\section{Degradation}

Degradation studies were performed with the formulation and the degraded samples were injected. Assay of the injected samples was calculated and all the samples passed the limits of degradation. The results were tabulated in Table 14, 15, 16.

\section{DISCUSSION}

The analytical method was developed by studying different parameters. First of all, maximum absorbance was found to be at $225 \mathrm{~nm}$ and the peak purity was excellent. Injection volume was selected to be $10 \mu$ l which gave a good peak area (figure 4). The column used on $\mathrm{C} 18150 \times 4.6 \mathrm{~mm}, 5 \mu$. was chosen good peak shape. Ambient temperature was found to be suitable for the nature of drug solution. The flow rate was fixed at $0.8 \mathrm{ml} / \mathrm{min}$ because of good peak area and satisfactory retention time. Different $\mathrm{pH}$ and ratios of mobile phase were studied, mobile phase with ratio of 65:35 buffers: Acetonitirile was fixed due to good symmetrical peak. So this mobile phase was used for the proposed study. Diluent methanol was selected because of maximum extraction, sonication time was fixed to be $10 \mathrm{~min}$ at which all the drug particles were completely soluble and showed good recovery. Run time was selected to be $12 \mathrm{~min}$ because analyze gave peak around 4.0 and also to reduce the total run time. The percent recovery was found to be $99.95 \% 99.96 \%$ and $99.66 \%$ was linear and precise over the same range. Both system and method precision was found to be accurate and well within range. In specificity study all degradant impurity and excipient peaks were separated from the analyse peak. Detection limit was found to be $0.001 \mu \mathrm{g} / \mathrm{ml}$. Linearity study was, correlation coefficient and curve fitting was found to be $10 \mu \mathrm{g} / \mathrm{ml}$. The analytical method was found linearity over the range of $2-10 \mu \mathrm{g} / \mathrm{ml}$ of the target concentration. The analytical passed both robustness and ruggedness tests. On both cases, relative standard deviation was all satisfactory

\section{CONCLUSION}

A simple, accurate, precise method was developed for the simultaneous estimation of the Abacavir, Lamivudine and Dolutegravir in Tablet dosage form. Retention time of Abacavir, Lamivudine and Dolutegravir were found to be $2.338 \mathrm{~min}, 3.276 \mathrm{~min}$ and 3.870 min. \%RSD of system precision for Abacavir, Lamivudine and Dolutegravir were and found to be $0.4,0.4$ and 0.4 respectively. \%RSD of method precision for Abacavir, Lamivudine and Dolutegravir. were and found to be 0.8 , 0.7 and 0.8 respectively. \% recovery was obtained as $99.95 \%, 99.96 \%$ and $99.66 \%$ for Abacavir, Lamivudine and Dolutegravir Respectively. LOD values are obtained from regression equations of Abacavir, Lamivudine and Dolutegravir. Were $0.75 \mathrm{ppm}, 1.80 \mathrm{ppm}$, $0.02 \mathrm{ppm}$ and $L O Q$ values are obtained from regression equations of Abacavir, Lamivudine and Dolutegravir? Were 2.288ppm, 2.28ppm, $1.80 \mathrm{ppm}$ respectively Regression equation of Abacavir. Was $y=15367 x+28649$, Lamivudine was $y=23710 x+24093$ and of Dolutegravir was $y=12067 x+1398$. Retention times are decreased so the method developed was simple and economical that 
can be adopted in regular Quality control test<smiles></smiles>

Fig. 1: Chemical Structure of Abacavir in Industries.<smiles>Nc1ccn([C@@H]2CS[C@H](CO)O2)c(=O)n1</smiles>

Fig. 2: chemical structure of Lamivudine<smiles>C[C@H]1CCO[C@@H]2Cn3cc(C(=O)NCc4ccc(F)cc4F)c(=O)c(O)c3C(=O)N12</smiles>

Fig. 3: Chemical Structure of Dolutegravir

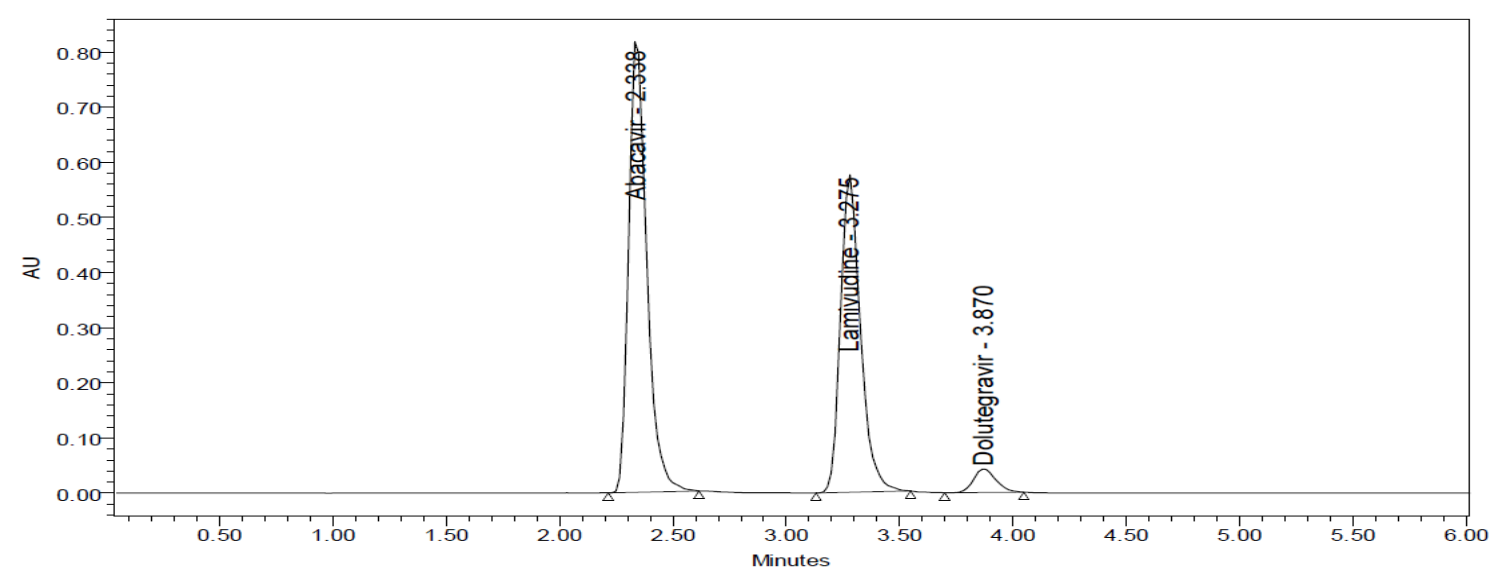

Fig. 4: RP-HPLC data of Abacavir Lamivudine and Dolutegravir 
Table 1: System suitability parameters for

Abacavir, Lamivudine, and Dolutegravir

\begin{tabular}{|c|c|c|c|c|c|c|c|c|c|}
\hline S no & \multicolumn{3}{|c|}{ Abacavir } & \multicolumn{3}{c|}{ Lamivudine } & \multicolumn{3}{c|}{ Dolutegravir } \\
\hline Inj & RT(min) & TP & Tailing & RT(min) & TP & Tailing & RT(min) & TP & Tailing \\
\hline 1 & 2.337 & 4563 & 1.38 & 3.273 & 6231 & 1.27 & 3.860 & 7218 & 1.18 \\
\hline 2 & 2.338 & 4067 & 1.35 & 3.274 & 6221 & 1.27 & 3.862 & 8063 & 1.16 \\
\hline 3 & 2.338 & 5098 & 1.33 & 3.276 & 6192 & 1.26 & 3.864 & 7463 & 1.18 \\
\hline 4 & 2.338 & 4598 & 1.34 & 3.276 & 7187 & 1.21 & 3.865 & 6727 & 1.15 \\
\hline 5 & 2.338 & 4340 & 1.28 & 3.277 & 7060 & 1.25 & 3.868 & 7039 & 1.14 \\
\hline 6 & 2.339 & 4013 & 1.38 & 3.278 & 6571 & 1.27 & 3.870 & 7347 & 1.16 \\
\hline
\end{tabular}

Table 2: Linearity for Abacavir, Lamivudine and Dolutegravir

\begin{tabular}{|c|c|c|c|c|c|}
\hline \multicolumn{2}{|c|}{ Abacavir } & \multicolumn{2}{c|}{ Lamivudine } & \multicolumn{2}{c|}{ Dolutegravir } \\
\hline Conc $(\boldsymbol{\mu} \mathbf{g} / \mathbf{m L})$ & Peak area & Conc $(\boldsymbol{\mu g} / \mathbf{m L})$ & Peak area & Conc $(\boldsymbol{\mu g} / \mathbf{m L})$ & Peak area \\
\hline 75 & 1251999 & 37.5 & 968599 & 6.25 & 77956 \\
\hline 150 & 2304223 & 75 & 1779302 & 12.5 & 157911 \\
\hline 225 & 3470543 & 112.5 & 2670001 & 18.75 & 224377 \\
\hline 300 & 4623169 & 150 & 3578843 & 25 & 298578 \\
\hline 375 & 5806354 & 187.5 & 4497785 & 31.25 & 377238 \\
\hline 450 & 6948004 & 225 & 5345952 & 37.5 & 457476 \\
\hline
\end{tabular}

Table 3: System precision table of Abacavir, Lamivudine and Dolutegravir

\begin{tabular}{|c|c|c|c|}
\hline S. No & $\begin{array}{c}\text { Area of } \\
\text { Abacavir }\end{array}$ & $\begin{array}{c}\text { Area of } \\
\text { Lamivudine }\end{array}$ & $\begin{array}{c}\text { Area of } \\
\text { Dolutegravir }\end{array}$ \\
\hline 1. & 4686224 & 3612387 & 302289 \\
\hline 2. & 4636238 & 3593729 & 300961 \\
\hline 3. & 4672357 & 3614257 & 300068 \\
\hline 4. & 4652001 & 3618927 & 300974 \\
\hline 5. & 4658919 & 3627707 & 300120 \\
\hline 6. & 4690287 & 3629255 & 303384 \\
\hline Mean & 4661960 & 3616044 & 301299 \\
\hline S.D & 20838.3 & 12910.4 & 1300.2 \\
\hline \%RSD & 0.4 & 0.4 & 0.4 \\
\hline
\end{tabular}

Table 4: Repeatability table of

Abacavir, Lamivudine and Dolutegravir

\begin{tabular}{|c|c|c|c|}
\hline S. No & $\begin{array}{c}\text { Area of } \\
\text { Abacavir }\end{array}$ & $\begin{array}{c}\text { Area of } \\
\text { Lamivudine }\end{array}$ & Area of Dolutegravir \\
\hline 1. & 4625380 & 3601311 & 299816 \\
\hline 2. & 4659369 & 3627867 & 298874 \\
\hline 3. & 4609685 & 3673450 & 299896 \\
\hline 4. & 4676038 & 3654222 & 304482 \\
\hline 5. & 4597715 & 3642452 & 302870 \\
\hline 6. & 4679396 & 3626342 & 298963 \\
\hline Mean & 4641264 & 3637607 & 300817 \\
\hline S.D & 35034.6 & 24993.7 & 2311.3 \\
\hline \%RSD & 0.8 & 0.7 & 0.8 \\
\hline
\end{tabular}

Table 5: Intermediate precision table of Abacavir, Lamivudine and Dolutegravir

\begin{tabular}{|c|c|c|c|}
\hline S. No & $\begin{array}{c}\text { Area of } \\
\text { Abacavir }\end{array}$ & $\begin{array}{c}\text { Area of } \\
\text { Lamivudine }\end{array}$ & $\begin{array}{c}\text { Area of } \\
\text { Dolutegravir }\end{array}$ \\
\hline 1. & 4564106 & 3529797 & 291524 \\
\hline 2. & 4552453 & 3555081 & 299693 \\
\hline 3. & 4506063 & 3532325 & 294205 \\
\hline 4. & 4595735 & 3594791 & 297008 \\
\hline 5. & 4551771 & 3560497 & 291616 \\
\hline 6. & 4572979 & 3563144 & 297291 \\
\hline Mean & 4557185 & 3555939 & 295223 \\
\hline S.D & 29828.2 & 23765.2 & 3321.8 \\
\hline \%RSD & 0.7 & 0.7 & 1.1 \\
\hline
\end{tabular}


Table 6: Accuracy table of Abacavir

\begin{tabular}{|c|c|c|c|c|}
\hline \%Level & $\begin{array}{l}\text { Amount Spiked } \\
\qquad(\mu \mathrm{g} / \mathrm{mL})\end{array}$ & $\begin{array}{l}\text { Amount } \\
\text { recovered } \\
(\mu \mathrm{g} / \mathrm{mL})\end{array}$ & \%Recovery & $\begin{array}{c}\text { Mean } \\
\text { \%Recovery }\end{array}$ \\
\hline \multirow{3}{*}{$50 \%$} & 150 & 149.04 & 99.36 & \multirow{9}{*}{99.95} \\
\hline & 150 & 151.69 & 101.13 & \\
\hline & 150 & 148.92 & 99.28 & \\
\hline \multirow{3}{*}{$100 \%$} & 300 & 297.49 & 99.16 & \\
\hline & 300 & 300.09 & 100.03 & \\
\hline & 300 & 300.91 & 100.30 & \\
\hline \multirow{3}{*}{$150 \%$} & 450 & 447.09 & 99.35 & \\
\hline & 450 & 451.92 & 100.43 & \\
\hline & 450 & 452.17 & 100.48 & \\
\hline
\end{tabular}

Table 7: Accuracy table of Lamivudine

\begin{tabular}{|c|c|c|c|c|}
\hline \%Level & $\begin{array}{l}\text { Amount Spiked } \\
(\mu \mathrm{g} / \mathrm{mL})\end{array}$ & $\begin{array}{c}\text { Amount } \\
\text { recovered } \\
(\mu \mathrm{g} / \mathrm{mL})\end{array}$ & \%Recovery & $\begin{array}{c}\text { Mean } \\
\text { \%Recovery }\end{array}$ \\
\hline \multirow{3}{*}{$50 \%$} & 75 & 74.76 & 99.68 & \multirow{9}{*}{99.96} \\
\hline & 75 & 75.97 & 101.29 & \\
\hline & 75 & 75.07 & 100.09 & \\
\hline \multirow{3}{*}{$100 \%$} & 150 & 150.32 & 100.21 & \\
\hline & 150 & 149.41 & 99.61 & \\
\hline & 150 & 147.14 & 98.09 & \\
\hline \multirow{3}{*}{$150 \%$} & 225 & 226.52 & 100.67 & \\
\hline & 225 & 225.38 & 100.17 & \\
\hline & 225 & 224.53 & 99.79 & \\
\hline
\end{tabular}

Table 8: Accuracy table of Dolutegravir

\begin{tabular}{|c|c|c|c|c|}
\hline \%Level & $\begin{array}{l}\text { Amount Spiked } \\
(\mu \mathrm{g} / \mathrm{mL})\end{array}$ & $\begin{array}{l}\text { Amount } \\
\text { recovered } \\
(\mu \mathrm{g} / \mathrm{mL})\end{array}$ & \%Recovery & Mean \%Recovery \\
\hline \multirow{3}{*}{$50 \%$} & 12.5 & 12.54 & 100.31 & \multirow{9}{*}{99.66} \\
\hline & 12.5 & 12.58 & 100.62 & \\
\hline & 12.5 & 12.49 & 99.93 & \\
\hline \multirow{3}{*}{$100 \%$} & 25 & 24.71 & 98.85 & \\
\hline & 25 & 24.80 & 99.21 & \\
\hline & 25 & 25.06 & 100.22 & \\
\hline \multirow{3}{*}{$150 \%$} & 37.5 & 37.03 & 98.75 & \\
\hline & 37.5 & 37.26 & 99.37 & \\
\hline & 37.5 & 37.37 & 99.67 & \\
\hline
\end{tabular}

Table 9: Sensitivity table of Abacavir,

$$
\text { Lamivudine and Dolutegravir }
$$

\begin{tabular}{|c|c|c|}
\hline Molecule & LOD $(\boldsymbol{\mu g} / \mathbf{m l})$ & $\mathbf{L O Q}(\boldsymbol{\mu g} / \mathbf{m l})$ \\
\hline Abacavir & 0.75 & 2.28 \\
\hline Lamivudine & 1.80 & 5.47 \\
\hline Dolutegravir & 0.02 & 0.07 \\
\hline
\end{tabular}

Table 10: Robustness data for Abacavir, Lamivudine and Dolutegravir

\begin{tabular}{|c|c|c|c|c|}
\hline S.no & Condition & $\begin{array}{c}\text { \%RSD of } \\
\text { Abacavir }\end{array}$ & $\begin{array}{c}\text { \%RSD of } \\
\text { Cilnidipine }\end{array}$ & $\begin{array}{c}\text { \%RSD of } \\
\text { Dolutegravir }\end{array}$ \\
\hline 1 & Flow rate (-) $0.7 \mathrm{ml} / \mathrm{min}$ & 0.6 & 0.8 & 0.7 \\
\hline 2 & Flow rate (+) $0.9 \mathrm{ml} / \mathrm{min}$ & 0.4 & 0.4 & 1.2 \\
\hline 3 & Mobile phase (-) $70 \mathrm{~B}: 30 \mathrm{~A}$ & 1.0 & 0.2 & 1.1 \\
\hline 4 & Mobile phase (+) $60 \mathrm{~B}: 40 \mathrm{~A}$ & 0.5 & 0.7 & 1.0 \\
\hline 5 & Temperature $(-) 25^{\circ} \mathrm{C}$ & 0.1 & 0.7 & 1.2 \\
\hline
\end{tabular}




\begin{tabular}{|c|c|c|c|}
\hline 6 & Temperature $(+) 35^{\circ} \mathrm{C}$ & 0.5 & 0.7 \\
\hline & Table 11: Assay Data of Abacavir \\
\hline & \begin{tabular}{|c|c|c|c|}
\hline S.no & Standard Area & Sample area & $\%$ Assay \\
\hline 1 & 4686224 & 4625380 & 99.02 \\
\hline 2 & 4636238 & 4659369 & 99.74 \\
\hline 3 & 4672357 & 4609685 & 98.68 \\
\hline 4 & 4652001 & 4676038 & 100.10 \\
\hline 5 & 4658919 & 4597715 & 98.42 \\
\hline 6 & 4690287 & 4679396 & 100.17 \\
\hline Avg & 4661960 & 4641264 & 99.36 \\
\hline Stdev & 20838.3 & 35034.6 & 0.750 \\
\hline \%RSD & 0.4 & 0.8 & 0.8 \\
\hline
\end{tabular}
\end{tabular}

Table 12: Assay Data of Lamivudine

\begin{tabular}{|c|c|c|c|}
\hline S.no & Standard Area & Sample area & $\%$ Assay \\
\hline 1 & 627909 & 621933 & 99.23 \\
\hline 2 & 624112 & 626052 & 99.88 \\
\hline 3 & 628450 & 624919 & 99.70 \\
\hline 4 & 626366 & 622416 & 99.30 \\
\hline 5 & 625325 & 620675 & 99.02 \\
\hline 6 & 621050 & 623247 & 99.43 \\
\hline Avg & 625535 & 623207 & 99.43 \\
\hline Stdev & 2720.6 & 1984.3 & 0.32 \\
\hline$\%$ RSD & 0.4 & 0.3 & 0.32 \\
\hline
\end{tabular}

Table 13: Assay Data of Dolutegravir

\begin{tabular}{|c|c|c|c|}
\hline S.no & Standard Area & Sample area & $\%$ Assay \\
\hline 1 & 302289 & 299816 & 99.41 \\
\hline 2 & 300961 & 298874 & 99.10 \\
\hline 3 & 300068 & 299896 & 99.43 \\
\hline 4 & 300974 & 304482 & 100.96 \\
\hline 5 & 300120 & 302870 & 100.42 \\
\hline 6 & 303384 & 298963 & 99.13 \\
\hline Avg & 301299 & 300817 & 99.74 \\
\hline Stdev & 1300.2 & 2311.3 & 0.766 \\
\hline \%RSD & 0.4 & 0.8 & 0.8 \\
\hline
\end{tabular}

Table 14: Degradation Data of Abacavir

\begin{tabular}{|c|c|c|c|c|}
\hline S.No & $\begin{array}{c}\text { Degradation } \\
\text { Condition }\end{array}$ & $\begin{array}{c}\text { \% Drug } \\
\text { Degraded }\end{array}$ & $\begin{array}{c}\text { Purity } \\
\text { Angle }\end{array}$ & $\begin{array}{c}\text { Purity } \\
\text { Threshold }\end{array}$ \\
\hline 1 & Acid & 4.65 & 0.202 & 0.280 \\
\hline 2 & Alkali & 3.00 & 0.163 & 0.489 \\
\hline 3 & Oxidation & 1.87 & 0.250 & 0.280 \\
\hline 4 & Thermal & 0.68 & 0.145 & 0.286 \\
\hline 5 & UV & 0.68 & 0.100 & 0.286 \\
\hline 6 & Water & 0.79 & 0.143 & 0.285 \\
\hline
\end{tabular}

Table 15: Degradation Data of Lamivudine

\begin{tabular}{|c|c|c|c|c|}
\hline S.NO & $\begin{array}{c}\text { Degradation } \\
\text { Condition }\end{array}$ & $\begin{array}{c}\text { \% Drug } \\
\text { Degraded }\end{array}$ & $\begin{array}{c}\text { Purity } \\
\text { Angle }\end{array}$ & $\begin{array}{c}\text { Purity } \\
\text { Threshold }\end{array}$ \\
\hline 1 & Acid & 4.56 & 0.115 & 0.428 \\
\hline 2 & Alkali & 2.88 & 0.128 & 0.489 \\
\hline 3 & Oxidation & 1.79 & 0.116 & 0.411 \\
\hline 4 & Thermal & 0.96 & 0.129 & 0.455 \\
\hline 5 & UV & 0.70 & 0.125 & 0.484 \\
\hline 6 & Water & 0.117 & 0.117 & 0.448 \\
\hline
\end{tabular}

Table 16: Degradation Data of Dolutegravir

\begin{tabular}{|c|c|c|c|c|}
\hline S.NO & $\begin{array}{c}\text { Degradation } \\
\text { Condition }\end{array}$ & $\begin{array}{c}\text { \% Drug } \\
\text { Degraded }\end{array}$ & $\begin{array}{c}\text { Purity } \\
\text { Angle }\end{array}$ & $\begin{array}{c}\text { Purity } \\
\text { Threshold }\end{array}$ \\
\hline 1 & Acid & 4.97 & 0.342 & 0.365 \\
\hline 2 & Alkali & 2.90 & 0.252 & 0.376 \\
\hline 3 & Oxidation & 1.97 & 0.209 & 0.974 \\
\hline 4 & Thermal & 0.93 & 0.284 & 0.371 \\
\hline 5 & UV & 0.94 & 0.333 & 0.381 \\
\hline
\end{tabular}




\section{ACKNOWLEDGEMENTS}

The author of thankful to authorities of department of pharmaceutical analysis ,vikas college of pharmacy, jntuk university, Vissannapeta for providing necessary facilities, authors are also thankful to authorities of departments, the authors are thankful to spectrum labs.

\section{REFERENCES}

1. Chatwal and Anand KS. High performance liquid chromatography, Instrumental methods of chemical analysis. Himalaya publishers: Mumbai. $2010 ; 5^{\text {th }}$ edition 2.570-2.629.

2. Sharma. High performance liquid chromatography. Instrumental methods of chemical analysis, Goel publishers, Meerut. 2005; $24^{\text {th }}$ edition 295-300.

3. Dong HPLC Instrumentation and trends. Modern HPLC for practicing scientists. USA. 2006; $5^{\text {th }}$ edition 78-110.

4. Skoog H, DM West and Holler FJ. Fundamentals of Analytical Chemistry, Saunders College Publishing, Philadelphia. 1992; $9^{\text {th }}$ edition 1-3.

5. Corners KA. Textbook of Pharmaceutical Analysis, A Wiley- inter science Publication. $1967 ; 1^{\text {st }}$ edition 475-478.

6. Kasture KA, Wadodkar SG, Mahadik KR and More HN. Textbook of Pharmaceutical Analysis - II, Published by Nirali Prakashan. 2005;25 $5^{\text {th }}$ edition 256260.

7. Beckett and Stanlake AH. J.B. Practical Pharmaceutical Chemistry, Part 2, CBS Publishers and Distributors. 2002; $4^{\text {th }}$ edition 157-174.

8. Snyder, Kirklannd JJ and Glaijch LJ. Practical HPLC method development, New York. 1997; $2^{\text {ed }}$ edition 30-100.
9. Satinder and development Dong and

MW. Method Pharmaceutical analysis by HPLC. Newyork. 2005; $15^{\text {th }}$ edition 16-70.

10. Swartz and Ira Krull. Analytical method development and validation, Marcel Dekker, New York. 2009; $1^{\text {st }}$ edition 17-80.

11. Rajkumar Prava, Ganapathy Seru, Vamsi Krishna Pujala and Surendra Babu Lagu. RP-HPLC method development and validation for the simultaneous determination of lamivudine, abacavir and dolutegravir in pharmaceutical dosage forms. World J Pharm Sci. 2017;35(5):565- 365.

12. Saidulu $P$ and Mastanamma SK. Stability Indicating Gradient RP-HPLC Method for the Simultaneous Estimation of Lamivudine, Abacavir and Dolutegravir in bulk and their Combined Dosage Form. Int J Pharm Sci. 2016;37(2):249- 257.

13. Valli Purnima $B$, Santha Kumari $M$, Ramu G and Vijaya Bhaskara Reddy T. Validated Reversed Phase HPLC Method for Assay and Degradation Studies of Lamivudine, Abacavir Sulphate And Dolutegravir In Combined Dosage Form. Int J Res. 2016;6(20):1560-1565.

14. Pal N, Srinivas $A$ and Ravikumar $P$. Simultaneous HPLC Method Development and Validation for Estimation of Lamivudine, Abacavir and Dolutegravir in Combined Dosage Form with their Stability Studies. Asian journal of chemistry. 2016;2(28):273-276.

15. Nagubandi $N$ and Nagaraju $P$. Simultaneous estimation of abacavir, lamivudine and dolutegravir from its tablet dosage form by UPLC method. World J Pharm Sci. 2015;3(10):2135-2140. 